\title{
HOSPITAL BASED SCREENING FOR HIV (HUMAN IMMUNODEFICIENCY VIRUS) IN CHILDREN IN A LOW RISK POPULATION - CROSS-SECTIONAL OBSERVATIONAL STUDY
}

\author{
Showkat Hussain Tali1, Shagufta Yousuf², Kaisar Ahmad Kaul ${ }^{3}$ \\ ${ }^{1}$ Assistant Professor, Department of Paediatrics, AIMSR, Bathinda, Punjab. \\ ${ }^{2}$ Assistant Professor, Department of Obstetrics \& Gynaecology, AIMSR, Bathinda, Punjab. \\ ${ }^{3}$ Professor, Department of Paediatrics, Government Medical College, Srinagar, Jammu and Kashmir.
}

\section{ABSTRACT}

\section{BACKGROUND}

Human Immunodeficiency Virus (HIV) infection is detected in a significant number of children globally. Since mass screening for detection of HIV infection in children is not feasible in a low risk and resource limited state, it is worthwhile to find out these cases among groups with high probability of the infection.

The aim of this study is to determine the probability of HIV infection, in a very low risk population, when a child is hospitalised with at least one of the selected manifestations that is known to be significantly associated with HIV infection.

\section{MATERIALS AND METHODS}

Hospitalised children aged between 19 months and 12 years admitted with predefined clinical pointers were screened for HIV infection by Micro-ELISA Kits. Positive micro-ELISA cases were subjected to Comb-Aid immune-blot test. Children positive for Immunoblot test as well were considered HIV positive cases.

\section{RESULTS}

Hundred patients were enrolled in the study. Four patients were detected of having HIV infection. Clinical pointers in these cases were fever (75\%), hepatomegaly (75\%), protein energy malnutrition (75\%), cough (50\%), recurrent bacterial infections $(50 \%)$, generalised dermatitis (50\%), diarrhoea (50\%) and oral thrush (50\%). Clinical pointers with significant positive correlation were recurrent bacterial infections, oral thrush and generalised dermatitis $(\mathrm{p}<0.05)$.

\section{CONCLUSION}

Hospital-based screening using specific clinical pointers is a useful tool to detect HIV Sero-positive cases in a low risk population.

\section{KEYWORDS}

Human Immunodeficiency Virus, Children, Selective Screening, Clinical Pointer.

HOW TO CITE THIS ARTICLE: Tali SH, Yousuf S, Kaul KA. Hospital based screening for HIV (Human immunodeficiency virus) in children in a low risk population - cross-sectional observational study. J. Evolution Med. Dent. Sci. 2017;6(7):550-553, DOI: 10.14260/Jemds/2017/117

\section{BACKGROUND}

An estimated 2.5 million children around the world are living with Human Immunodeficiency Virus (HIV)/Acquired Immunodeficiency Syndrome (AIDS) according to the 2010 report on the Global AIDS Epidemic released by Joint United Nations Program on HIV/AIDS. India has an estimated 220,000 children infected by HIV/AIDS. Women and children are increasingly becoming vulnerable to this disease. This alarming trend is being observed closely as more HIV positive mothers will unknowingly pass the virus on to their children. Children under 15 years of age account for $4.4 \%$ of all infections, while people aged 15 - 49 years account for $82.4 \%$ of all infections.(1)

Early diagnosis of HIV infection in a child is not only helpful in instituting prophylactic therapy, but also in

Financial or Other, Competing Interest: None.

Submission 14-12-2016, Peer Review 08-01-2017,

Acceptance 13-01-2017, Published 23-01-2017.

Corresponding Author:

Dr. Showkat Hussain Tali,

Assistant Professor,

Department of Paediatrics,

AIMSR, Bathinda, Punjab.

E-mail: drshowkatshifa@gmail.com

DOI: $10.14260 /$ jemds $/ 2017 / 117$ providing supportive care. However, undertaking diagnostic workup to screen all children for HIV infection in the low risk populations may not be that cost effective. When applied to the individuals with high probability of HIV infection in a low risk population, it is highly likely that cost effectiveness will be improved reasonably.(2,3) Although, several studies have been carried out in African countries(4-6) and many states of India(2,3,7) to determine the likelihood of HIV infection with a given clinical feature to the best of our knowledge. No such study has been carried out in the Kashmir division of Jammu and Kashmir state. As per NACO 2012 report, the state of Jammu and Kashmir falls among the states with the lowest HIV prevalence in India. ${ }^{(8)}$ Hence, we conducted a prospective study to determine the probability of HIV infection in a very low risk population, when a child is hospitalised with at least one of the selected manifestations that is known to be significantly associated with HIV infection.

\section{MATERIALS AND METHODS}

This cross-sectional observational study was carried out at GB Pant Children's Hospital, Srinagar, which is a tertiary care hospital for children in the state of Jammu and Kashmir, India. The study was approved by Institutional Research Board (IRB) and Ethical Committee of the College. All children aged between 19 months and 12 years and admitted with predefined clinical pointers (Table 1) were included in 
this study. Written informed consent from parent/guardian was taken prior to enrolment and screening. Pre-test counselling was provided to the parent or guardian of all patients regarding the nature of the study and implications thereof.

\begin{tabular}{|c|c|c|}
\hline $\begin{array}{l}\text { Sl. } \\
\text { No. }\end{array}$ & Clinical Pointer & Description \\
\hline 1 & Fever & $\begin{array}{c}\text { Documented Fever (Axillary } \\
\text { Temperature }>37.8^{\circ} \mathrm{C} \text { ) } \geq 1 \text { Month }\end{array}$ \\
\hline 2 & Diarrhoea & $\geq 2$ loose Stools per Day $\geq 1$ Month \\
\hline 3 & Persistent Cough & Cough $\geq 1$ Month \\
\hline 4 & Malnutrition & $\begin{array}{l}\geq \text { Grade } 3 \text { PEM as Defined by } \\
\text { Indian Academy of } \\
\text { Paediatrician's Classification }\end{array}$ \\
\hline 5 & Oral Thrush & $\begin{array}{l}\text { Presence of Whitish Plaques in } \\
\text { Oral Cavity which could not be } \\
\text { easily Removed without Leaving } \\
\text { an Erythematous Base }\end{array}$ \\
\hline 6 & $\begin{array}{c}\text { Generalised } \\
\text { Lymphadenopathy }\end{array}$ & $\begin{array}{c}\text { Enlarged Lymph Nodes ( }>1 \mathrm{~cm} \\
\text { in Axilla and }>1.5 \mathrm{~cm} \text { in Inguinal } \\
\text { Region) in } \geq 2 \text { Non-Contagious } \\
\text { Sites for }>2 \text { Months }\end{array}$ \\
\hline 7 & Hepatomegaly & $\begin{array}{c}\text { Liver below Costal Margin } \\
>4-7 \mathrm{~cm} \text { (As per age) } \\
\text { as Detected Clinically }\end{array}$ \\
\hline 8 & $\begin{array}{l}\text { Generalised } \\
\text { Dermatitis }\end{array}$ & $\begin{array}{c}\text { Including Eczema and } \\
\text { Maculopapular Dermatitis }\end{array}$ \\
\hline 9 & $\begin{array}{l}\text { Chronic } \\
\text { Parotid } \\
\text { Swelling } \\
\end{array}$ & $\begin{array}{l}\text { Swelling of at least } 1 \\
\text { Parotid Gland for a Minimum } \\
\text { Period of } 3 \text { Months }\end{array}$ \\
\hline 10 & $\begin{array}{l}\text { Recurrent } \\
\text { Bacterial } \\
\text { Infection }\end{array}$ & $\begin{array}{l}\text { Occurrence of }>2 \text { Episodes of } \\
\text { Serious Bacterial Infections } \\
\text { such as Pyogenic Meningitis } \\
\text { or Pneumonia in Past } 2 \text { Years }\end{array}$ \\
\hline 11 & $\begin{array}{l}\text { Disseminated } \\
\text { Tuberculosis }\end{array}$ & $\begin{array}{c}\text { Miliary Tuberculosis or } \\
\text { CNS Tuberculosis or Pulmonary } \\
\text { Tuberculosis in Conjunction } \\
\text { with Abdominal Tuberculosis }\end{array}$ \\
\hline 12 & $\begin{array}{c}\text { Pneumocystis } \\
\text { Carinii pneumoniae }\end{array}$ & $\begin{array}{c}\text { Diagnosed on the Basis } \\
\text { of Clinical Features, } \\
\text { Arterial Blood Gas Analysis, } \\
\text { Chest Radiography and } \\
\text { Microbiological Studies }\end{array}$ \\
\hline
\end{tabular}

After recruitment, details of demographic data, history and physical examination findings were recorded in a predesigned proforma. Five millilitres $(5 \mathrm{~mL})$ of venous blood were collected and were sent to laboratory for HIV screening by Micro-ELISA Kits. Micro-ELISA positive cases were subject to Comb-Aid immunoblot testing in sequence. When both the tests were positive, HIV was confirmed as per National AIDS Control Organisation (NACO) guidelines. CD4 count was done in every patient who was confirmed HIV positive. As a secondary end point of the study, the parents of children (children who eventually were HIV positive) were screened for HIV infection after offering pre-test counselling.

\section{Statistical Analysis}

The data was analysed using the SPSS software programme version 18. Chi-square test was used with Yates correction. Relative Risk and Odds Ratio were determined wherever applicable.

\section{RESULTS}

A total of 100 patients were enrolled in the study. Four were sero-positive for HIV infection. Baseline characteristics of the study population are depicted in Table 2 .

\begin{tabular}{|c|c|c|}
\hline Sl. No. & Age (Months) & No. of Patients \\
\hline 1 & $19-32$ & $6(6 \%)$ \\
\hline 2 & $33-46$ & $4(4 \%)$ \\
\hline 3 & $47-60$ & $9(9 \%)$ \\
\hline 4 & $61-74$ & $5(5 \%)$ \\
\hline 5 & $75-88$ & $7(7 \%)$ \\
\hline 6 & $89-102$ & $10(10 \%)$ \\
\hline 7 & $103-116$ & $17(17 \%)$ \\
\hline 8 & $117-130$ & $14(14 \%)$ \\
\hline \multirow[t]{3}{*}{9} & $131-144$ & $28(28 \%)$ \\
\hline & Total & $100(100 \%)$ \\
\hline & Gender & \\
\hline 1 & Male & $58(58 \%)$ \\
\hline \multirow[t]{2}{*}{2} & Female & $42(42 \%)$ \\
\hline & Total & $100(100 \%)$ \\
\hline \multicolumn{3}{|c|}{$\begin{array}{l}\text { Table 2. Age and Gender of } \\
\text { the Study Population }(n=100)\end{array}$} \\
\hline
\end{tabular}

No. of subjects (total and sero-positive) with a predefined clinical pointer are in shown in Table 3. Statistical analysis is shown in Table 4. Correlation of no. of risk factors with seropositivity is shown in Table 5. Demographic and other characteristics of HIV sero-positive cases are in Table 6.

\begin{tabular}{|c|c|c|c|}
\hline $\begin{array}{l}\text { Sl. } \\
\text { No. }\end{array}$ & $\begin{array}{l}\text { Clinical } \\
\text { Pointers }\end{array}$ & $\begin{array}{l}\text { Total No. of } \\
\text { Subjects } \\
\text { (Percentage); } \\
\text { N=100 }\end{array}$ & \begin{tabular}{|} 
No. of HIV Sero- \\
positive \\
Cases \\
(Percentage); \\
N=4
\end{tabular} \\
\hline 1 & Fever (> 1 month) & $48(48 \%)$ & $3(75 \%)$ \\
\hline 2 & $\begin{array}{c}\text { Diarrhoea } \\
(>1 \text { month })\end{array}$ & $12(12 \%)$ & $2(50 \%)$ \\
\hline 3 & Cough (>1 month) & $27(27 \%)$ & $2(50 \%)$ \\
\hline 4 & $\begin{array}{c}\text { Malnutrition } \\
\text { (Grade III or more) }\end{array}$ & $33(33 \%)$ & $3(75 \%)$ \\
\hline 5 & Oral Thrush & $4(4 \%)$ & $2(50 \%)$ \\
\hline 6 & $\begin{array}{c}\text { Generalised } \\
\text { Lymphadenopathy }\end{array}$ & $8(8 \%)$ & $2(50 \%)$ \\
\hline 7 & Hepatomegaly & $46(46 \%)$ & $3(75 \%)$ \\
\hline 8 & $\begin{array}{c}\text { Generalised } \\
\text { Dermatitis }\end{array}$ & $3(3 \%)$ & $2(50 \%)$ \\
\hline 9 & $\begin{array}{l}\text { Chronic Parotid } \\
\text { Swelling }\end{array}$ & $0(0 \%)$ & $0(0 \%)$ \\
\hline 10 & $\begin{array}{c}\text { Recurrent Bacterial } \\
\text { Infection }\end{array}$ & $8(8 \%)$ & $0(0 \%)$ \\
\hline 11 & $\begin{array}{l}\text { Disseminated } \\
\text { Tuberculosis } \\
\end{array}$ & $18(18 \%)$ & $0(0 \%)$ \\
\hline 12 & $\begin{array}{c}\text { Pneumocystis } \\
\text { Carinii Pneumoniae }\end{array}$ & $0(0 \%)$ & $0(0 \%)$ \\
\hline \multicolumn{4}{|c|}{$\begin{array}{l}\text { Table 3. Total No. of Subjects with a Specific } \\
\text { Clinical Pointer and No. of HIV Sero-Positive } \\
\text { Subjects having that Clinical Pointer }\end{array}$} \\
\hline
\end{tabular}

\section{DISCUSSION}

In our study, there was a statistically significant correlation between presence of recurrent bacterial infection, oral thrush and generalised dermatitis and the prediction of HIV infection sero-positivity ( $p<0.05)$. Although fever, severe malnutrition and hepatomegaly were the most common findings in HIV positive patients, they did not predict HIV sero-positivity. 


\begin{tabular}{|c|c|c|c|c|c|c|c|}
\hline $\begin{array}{c}\text { Clinical } \\
\text { Pointers }\end{array}$ & $\begin{array}{c}\text { HIV Sero- } \\
\text { Positive }\end{array}$ & $\begin{array}{c}\text { HIV Sero- } \\
\text { Negative }\end{array}$ & $\mathbf{X}^{2}$ & $\begin{array}{c}\mathbf{p} \\
\text { Valve }\end{array}$ & $\begin{array}{c}\text { Odds } \\
\text { Ratio }\end{array}$ & Specificity & Sensitivity \\
\hline Fever (> 1 Month) (n=27 & $3(6.25 \%)$ & $45(93.75 \%)$ & 0.35 & $>0.05$ & 4.05 & 53 & 75 \\
\hline Cough (>1 Month) (n = 27) & $2(7.4 \%)$ & $25(92.59 \%)$ & 0.233 & $>0.05$ & 1.35 & 74 & 50 \\
\hline Severe Malnutrition & $3(9.09 \%)$ & $30(90.90 \%)$ & 1.64 & $>0.05$ & 3.45 & 69 & 75 \\
\hline Recurrent Bacterial Infection (n = 9) & $2(25 \%)$ & $6(75 \%)$ & 5.38 & $<0.05 \pi$ & 1.04 & 94 & 50 \\
\hline Generalised Dermatitis (n 3) & $2(66.66 \%)$ & $1(33.33 \%)$ & 17.04 & $<0.05 \pi$ & 1.010 & 99 & 50 \\
\hline Hepatomegaly (n = 46) & $3(6.97 \%)$ & $43(93.4 \%)$ & 0.456 & $>0.05$ & 3.81 & 55 & 75 \\
\hline Chronic Diarrhoea (n 12) & $2(16.66 \%)$ & $10(83.33 \%)$ & 2.56 & $>0.05$ & 1.16 & 89 & 50 \\
\hline Oral Thrush & $2(50 \%)$ & $2(50 \%)$ & 12.17 & $<0.05 \pi$ & 1.02 & 98 & 50 \\
\hline
\end{tabular}

$\pi=P$ value Statistically Significant

The strength of our study is that it has shown the feasibility of applying clinical pointer based screening tool in a very low risk population for HIV infection detection. However, the results of our study would not be applicable to screening of asymptomatic children as our target population were symptomatic in hospitalised children. Furthermore, children aged 18 months and younger were not enrolled as diagnosing HIV infection in them would need performance of HIV, DNA, PCR which was not possible because of economical constraints.

Common clinical manifestations in HIV positive patients were fever $(75 \%)$, severe malnutrition $(75 \%)$, hepatomegaly (75\%), cough for more than one month (50\%), chronic diarrhoea $(50 \%)$, recurrent bacterial infection $(50 \%)$, oral thrush $(50 \%)$ generalised dermatitis $(50 \%)$. These findings are consistent with other published studies.[9,10] Although, generalised lymphadenopathy is a common presenting risk factor for HIV in hospitalised children,[2,7] our observation did not reveal any such finding. Also, no case of disseminated tuberculosis was reported in our study, which is also a common clinical pointer[11] for detecting HIV sero-conversion in this population. This may be due to the fact that less number of subjects was enrolled in our study.

In this study, generalised dermatitis, oral thrush and recurrent bacterial infections were significant predictors for detection of HIV positivity rate $(\mathrm{p}<0.05)$, which is consistent with other studies.[12,13,3] Patients with single clinical risk factor had a sero-positivity rate of $3.7 \%$, patients with 5 clinical risk factors had sero-positivity rate of $50 \%$ and those with 6 or 7 such factors predicted a rate of $100 \%$. This study shows that as the number of predefined clinical risk factors increases, the probability of sero-conversion to HIV also increases. This finding correlates well with the findings of other studies.(3)

\begin{tabular}{|c|c|c|c|}
\hline $\begin{array}{c}\text { No. of } \\
\text { Risk } \\
\text { Factors } \\
\text { Present }\end{array}$ & $\begin{array}{c}\text { HIV } \\
\text { Positive } \\
\text { Cases (n = 4)/ } \\
\text { Percent } \\
\text { of Total }\end{array}$ & $\begin{array}{c}\text { HIV } \\
\text { Negative } \\
\text { Cases } \\
(\mathbf{n = 9 6 )}\end{array}$ & $\begin{array}{c}\text { Total No. of } \\
\text { Subjects with } \\
\text { the Clinical } \\
\text { Pointer } \\
\text { (n= 100) }\end{array}$ \\
\hline 1 & $1(3.7 \%)$ & 27 & $(28)$ \\
\hline 2 & $0(0 \%)$ & 41 & $(41)$ \\
\hline 3 & $0(0 \%)$ & 22 & $(22)$ \\
\hline 4 & $0(0 \%)$ & 5 & $(05)$ \\
\hline 5 & $1(50 \%)$ & 1 & $(02)$ \\
\hline 6 & $1(100 \%)$ & 0 & $(01)$ \\
\hline 7 & $1(100 \%)$ & 0 & $(01)$ \\
\hline \multicolumn{4}{|c|}{$\begin{array}{c}\text { Table 5. Risk Factor Correlation } \\
\text { (HIV Positive Vs HIV Negative) }\end{array}$} \\
\hline
\end{tabular}

In our study, all HIV sero-positive cases were from rural areas. This may be related to low education level and lack of healthcare awareness in such populations.

At the time of admission in the hospital, there was no family history of HIV infection or AIDS in any of the studied 100 patients including HIV positive cases. On contact tracing, first patient had both mother and father positive for HIV infection. The other two patients (siblings) provided history of prolonged maternal illness (pulmonary tuberculosis) and death, although no HIV testing was performed on her. The fourth patient's mother had died of recurrent pneumonias, but was never screened for HIV infection. None of the affected patients had received any blood transfusion. There was no history of sexual abuse or repeated syringe use in any of the affected patients (Table 5). So most probably the transmission of the disease was vertical, which is consistent with other studies.(14)

\begin{tabular}{|c|c|c|c|c|c|c|}
\hline $\begin{array}{c}\text { Case } \\
\text { No. }\end{array}$ & $\begin{array}{c}\text { Mother } \\
\text { Sero-Positive }\end{array}$ & $\begin{array}{c}\text { Father } \\
\text { Sero-Positive }\end{array}$ & $\begin{array}{c}\text { Blood Transfusion/Sexual } \\
\text { Abuse/Exposure to Injections }\end{array}$ & $\begin{array}{c}\text { Male (M)/ } \\
\text { Female (F) }\end{array}$ & $\begin{array}{c}\text { Rural (R)/ } \\
\text { Urban (U) }\end{array}$ & $\begin{array}{c}\text { CD4 Count/ } \\
\text { mm }^{\mathbf{3}}\end{array}$ \\
\hline 1 & Yes & Yes & No & F & R & 1340 \\
\hline $2 \Omega$ & $? ¥$ & No & No & M & R & 560 \\
\hline $3 \Omega$ & $? ¥$ & No & No & F & R & 350 \\
\hline 4 & $? €$ & Yes & No & Table 6. Demographic and other Characteristics of HIV Sero-Positive Cases \\
\hline \multicolumn{7}{|r}{}
\end{tabular}

$¥=$ Mother had died of pulmonary tuberculosis, but never tested for HIV. $€=$ Mother had died of recurrent chest infections, but never tested for HIV. $\Omega$ = Siblings.

\section{CONCLUSION}

Our study suggests that the hospital-based, clinically-directed screening has a practical role in diagnosis of HIV infection in a resource limited settings even in low prevalence population. Moreover, contact tracing may be an effective tool in searching for hidden HIV infected cases. 


\section{REFERENCES}

[1] Pandey A, Sahu D, Bakkali T, et al. Estimate of HIV prevalence and number of people living with HIV in India 2008-2009. BMJ Open 2012;2(5):e000926.

[2] Ojukwu JU, Ogbu CN. HIV infection in hospitalized children with endemic diseases in Abakaliki, Nigeria: the role of clinically directed selective screening in diagnosis. AIDS Care 2007;19(3):330-6.

[3] Bavdekar SB, Agarwal R. Clinically directed selective screening for HIV infection in hospitalized children. Indian Pediatr 2005;42(12):1191-7.

[4] Esamai F, Buku GM. HIV sero-positivity in children admitted with diarrhoea at Eldoret district hospital, Kenya. E Afr Med J 1994;71(10):631-4.

[5] Lepage P, Van de Perre P, Nsengumuremye F, et al. Bacteremia as predictor of HIV infection in African children. Acta Paediatr Scand 1989;78(5):763-6.

[6] Pallangyo K, Hakanson A, Lema L, et al. High HIV seroprevalence and increased HIV-associated mortality among hospitalized patients with deep bacterial infections in Dar es Salaam, Tanzania. AIDS 1992;6(9):971-6.

[7] Emodi IJ, Okafor GO. Clinical manifestations of HIV infection in children at Enugu, Nigeria. J Trop Pediatr 1998;44(2):73-6.
[8] NACO (2012) 'HIV Sentinel Surveillance 2010-2011, a Technical Brief'. Accessed on June 2014.

[9] Merchant RH, Oswal JS, Bhagwat RV, et al. Clinical profile of HIV infection. Indian Pediatr 2001;38(3):239-46.

[10] Pol RR, Shepur TA, Ratageri VH. Clinico-laboratory profile of pediatric HIV in Karnataka. Indian J Pediatr 2007;74(12):1071-5.

[11] Merchant RH, Shroff RC. HIV sero-prevalence in disseminated tuberculosis and chronic diarrhoea. Indian Pediatr 1998;35(9):883-7.

[12] Lodha R, Singhal T, Jain Y, et al. Paediatric HIV infection in a tertiary care centre in north India: early impressions. Indian Pediatr 2000;37(9):982-6.

[13] Madhivanan P, Mothi SN, Kumarasamy N, et al. Clinical manifestations of HIV infected children. Indian J Pediatr 2003;70(8):615-20.

[14] Coutsoudis A, Kwaan L, Thomson M. Prevention of vertical transmission of HIV-1 in resource-limited settings. Expert Review of Anti-Infective Therapy 2010;8(10):1163-75. 